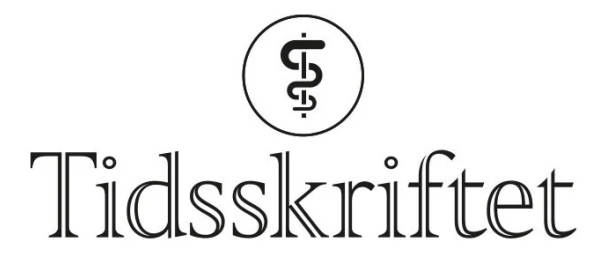

DEN NORSKE LEGEFORENING

\title{
Evidensen for medisinsk behandling av AD/HD er usikker
}

KOMMENTAR

\section{OLE JAKOB STOREB $\varnothing$}

ojst@regionsjaelland.dk

Ole Jakob Storebø er seniorforsker

Ingen oppgitte interessekonflikter.

Denne artikkelen beskriver den historiske utviklingen av evidensgrunnlaget for medisinsk behandling med $\mathrm{AD} / \mathrm{HD}$ godt. Vi er for øyeblikket $\mathrm{i}$ avslutningsfasen av et oppfølgende Cochrane systematiske review om metylfenidat som fokuserer på bivirkninger av medisinen, unders $ø$ kt i kohorte studier. Reviewet, som snart vil bli publisert, inkluderer over to millioner pasienter og er avslutningen på åtte års grundig systematisering og analyser av metylfenidates gavnlige og skadelige virkninger. Dette reviewet vil skape ytterliggere debatt (1).

Evidensgrunnlaget for gavnlige effekter er temmelig tynt, som denne artikkelen korrekt beskriver. Når det er sagt er det viktig å være oppmerksom på at evidensbegrepet består av flere elementer. David Sacket understrekte hvor viktig det var at pasienten var omdreiningspunktet for den evidensbaserte behandling, og han påpekte også at klinikernes erfaring var sentral, forutenom den eksterne evidens (randomiserte kliniske fors $ø \mathbf{k})(\underline{2})$. Evidensbasert praksis er grundig, fornuftig og gjennomtenkt bruk av den beste evidens i forbindelse med beslutninger omkring behandling av den enkelte pasient (3). Våre to Cochrane systematiske reviews om metylfenidat representerer deler av den eksterne evidens $(\mathbf{1}, 4$.$) , men de skal også relateres til de to andre viktige delelementer i$ evidensbegrepet: pasientenes preferanser og klinikernes erfaringer.

Det er mange klinikere, pasienter og foreldre som opplever at enkelte med AD/HD utviser god effekt av metylfenidat, og dette er viktig å respektere. Vår forskning viser at vi vet lite om den sanne størrelsen av effekten, og det er også flere bivirkninger. God rådgiving $\mathrm{i}$ forbindelse med bruk av metylfenidat er derfor å lytte til pasienters ønsker, samt å rådgive om den eksterne evidens på en objektiv måte, hvor man også inndrar klinikerens erfaring. Evidensbasert behandling må ikke bli et «behandlertyrani» $(\mathbf{1}, 5)$.

\section{LITTERATUR}

1. Storebø OJ, Pedersen N, Ramstad E et al. doi:10.1136/bmj.312.7023.71. Methylphenidate for attention deficit hyperactivity disorder (ADHD) in children and adolescents - assessment of harmful effects in 
non-randomised studies. Cochrane Database Syst Rev 2015; 11: CDoog885.[CrossRef]

2. Sackett DL, Rosenberg WM, Gray JAM et al. Evidence based medicine: what it is and what it isn't. BMJ 1996; 312: 71 - 2. [PubMed][CrossRef]

3. Storebø OJ, Simonsen E. Evidensbaseret behandling, de generelle behandlingsprincipper og gode råd. I: Simonsen E, Mathiesen BB, red. Personlighed og Personlighedsforstyrrelser. En Grundbog. København: Hans Reitzels Forlag, 2017.

4. Storebø OJ, Ramstad E, Krogh $\mathrm{H}$ et al. Methylphenidate for children and adolescents with attention deficit hyperactivity disorder (ADHD). Cochrane Database Syst Rev 2015; 11. [PubMed]

5. Tyrer P. A patient who changed my practice: The case for patient-based evidence versus trial-based evidence. Int J Psychiatry Clin Pract 2000; 4: 253 - 5. [PubMed][CrossRef]

Publisert: 16. mars 2018. Tidsskr Nor Legeforen. DOI: 10.4045/tidsskr.18.0182

(C) Tidsskrift for Den norske legeforening 2023. Lastet ned fra tidsskriftet.no 26. april 2023. 